Arab Univ. J. Agric. Sci., Ain Shams Univ., Cairo, 13(3), 825 - 839, 2005

\title{
FORTIFICATION OF PROCESSED CHEESE SPREAD WITH ACCUSTOMED EDIBLE MUSHROOM
}

[55]

\author{
Fatma A. Fathi ${ }^{1}$; Gehan A.M. Hussein ${ }^{2}$ and A.G. Mohamed ${ }^{1}$
}

\begin{abstract}
The effect of incorporating accustomed edible mushroom (Agaricus campestris) into processed cheese spread (PCSs) on the chemical, microbiological and organoleptic properties was evaluated. Tiny pieces of mushroom accustomed with steeping into citric acid and boiling in emulsifying salt solution were added to the blend of the cheese spread base at the levels of 5,10 and $15 \%$. The resulting PCSs were stored at $7^{\circ} \mathrm{C}$ for 3 months. Significant differences $(p<0.05)$ were recorded among the chemical composition of PCSs made without and with addition of mushroom. The incorporation of mushroom into PCSs resulted in higher contents of total solids, total protein, $\mathrm{SN}$, ash, total carbohydrates and fiber, as well as $\mathrm{pH}$ values than the control spread. On the other hand, control treatment made without mushroom possessed the highest content in F/DM. Addition of mushroom to the base blend did not significantly affect $(p>0.05)$ in the salt and TVFA contents. The standard plate and psychrotrophic counts of PCSs made without and with mushroom showed slight differences when fresh and during the storage period. The standard plate counts slightly increased during the storage period reaching the maximum counts after one month, and then decreased with prolonged storage. Psychrotrophic bacteria gradually increased in all treatments throughout the storage period. On the other hand, no colonies were found from yeasts and molds, coliform and mesophilic anaerobic spores in all samples examined. Obvious differences $(p<0.05)$ were noticed in the organoleptic evaluation scores among all treatments of PCSs. The flavours of PCSs with mushroom were generally better and preferable when fresh and throughout the storage period. Addition of $15 \%$ mushroom caused an over pieces of mushroom, which defected the body \& texture and appearance \& colour of the resulting spread. Therefore, PCSs with improved nutritional and functional values as well as acceptable organoleptic properties and good microbiological quality could be made by incorporation of accustomed edible mushroom into the base blend at the levels of 5 and $10 \%$ with refrigerated expiry period more than 3 months.
\end{abstract}

Key words: Processed cheese spread; Accustomed edible mushroom; Chemical properties; Microbiological properties; Organoleptic properties

1- Dairy Science Dept., National Research Center, Dokki, Giza, Egypt.

2- Food Sci. Dept., Fac. Agric., Ain Shams Univ., Shoubra EL-Khaima, Cairo, Egypt.

(Received May 11, 2005)

(Accepted June 8, 2005) 
Arab Univ. J. Agric. Sci., Ain Shams Univ., Cairo, 13(3), 825 - 839, 2005

\section{INTRODUCTION}

Processed cheese is a product obtained by blending cheeses of different types and maturity, with melting salts. This mixture is ground, then heated under partial vacuum with constant stirring until a homogeneous mass is obtained, then packaged in a protective film. Other raw materials of dairy origin (butter, milk powder) or aromatic ingredients can also be added (Chambre \& Daurelles, 2000). Certain processed cheeses are aromatized by a supply of aroma ingredients of animal (ham, salami, smoked beef, seafood, fish, salmon and prawns, etc.) or plant (spices, herbs, vegetables and fruits, etc.) origin. These ingredients consist mostly of highly perishable rich protein, which are restricted to a maximum of 15 $\%$, do not influence the consistency and structure of processed cheese to any appreciable extent, providing that these are bacteriologically satisfactory (Meyer, 1973). These food additives are sometimes added at the beginning of the process and occasionally towards the end. If added at the beginning, there is the definite advantage of better pasteurization of the additives but, on the other hand, susceptible foods, such as mushrooms, shrimps, sardines, fruits, tomatoes, etc., can be badly bruised by the agitation in the cooker. When the cheese is homogenized, the additives must, of course, be added at the end of the process. It is somewhat superfluous to indicate that additives of only first class quality should be used to guarantee the flavour, appearance and keeping quality of the cheese spread. When dried food ingredients, such as mushrooms, are used, they should be subjected to sterilization before being used unless of course short time high temperature cooking is to be employed (i.e. well over $100^{\circ} \mathrm{C}$ ).

Since earliest times, mushrooms have been treated as a special kind of food (Chang \& Miles, 1993). The total annual world production of cultivated mushrooms is estimated at well over 1.2 million metric tons (Breene, 1990). The fast-growing mushrooms have received a remarkable amount of interest in recent decades with the realization that they are a good source of delicious food with high nutritional attributes, and some have medical values as well. Mushrooms may be consumed for their palatability and / or nutritional value. Palatability can be judged by color, texture, flavour and taste, but the nutritional value requires much scientific work. Analyses of the proximate composition of the commonly cultivated mushrooms reveal that edible mushrooms are rich in crude protein and carbohydrates, moderate in crude fiber and ash, and low in fat content (Lau, 1982). The energy values are low. They are a good source of essential amino acids, vitamins and minerals. On a dry weight basis, mushrooms normally contain 19 to $35 \%$ protein, as compared to $25.2 \%$ in milk (Crisan \& Sands, 1978 and Li \& Chang, 1982a). In $100 \mathrm{~g}$ of crude protein (calculated as $4.38 \times$ total nitrogen) there is 32 to $48 \mathrm{~g}$ of the 9 essential amino acids (Weaver $\boldsymbol{e t}$ al

1- Dairy Science Dept., National Research Center, Dokki, Giza, Egypt.

2- Food Sci. Dept., Fac. Agric., Ain Shams Univ., Shoubra EL-Khaima, Cairo, Egypt.

(Received May 11, 2005)

(Accepted June 8, 2005) 
1977). Of these, lysine is the most abundant, while tryptophane and methionine are low. At least $72 \%$ of the total fatty acids were found in the mushrooms to be unsaturated. Unsaturated fatty acids are essential in our diet (Holman, 1976), whereas saturated fatty acids, which are present in high amounts in animal's fats, may be harmful to our health. The finding of a high proportion of unsaturated fatty acids and a high percentage of linoleic acid in these mushrooms is a significant factor in regarding mushrooms as a healthy food. The mushrooms contain a substantial amount of thiamine (vitamin B2), riboflavin, niacin and provitamin- D2; as well as biotin and ascorbic acid (vitamin C) (Crisan \& Sands, 1978). Recently, much interest has arisen in characterizing the components of water-soluble polysaccharides obtained from the fruiting bodies of mushrooms (Yoshioka et al 1975) because of their ability to inhibit the growth of tumors. Fiber is considered to be an important ingredient in a balanced and healthy diet. The fiber content ranges from 7.4 to $27.6 \%$ in some mushrooms species. Anderson \& Ward (1979) reported that feeding diabetic patents with high fiber diets reduces their daily insulin requirement and stabilizes their blood glucose profile, possibly by decreasing the rate of glucose absorption and/or delaying gastric emptying. It is calculated that the concentration of $\mathrm{K}, \mathrm{P}, \mathrm{Na}, \mathrm{Ca}$ and $\mathrm{Mg}$ constitute about 56 to $70 \%$ of the total ash content ( $\mathbf{L i} \&$ Chang, 1982 a).

Potassium and phosphorus are the two dominant elements in the mineral portion. The nucleic acid content of mushrooms is within the range $(2.7-4.1 \%$ dry weight $)$ of other filamentous fungi $(3.2-4.7 \%$ dry weight) and is much lower than that of the rapidly growing bacteria $(8.0-$ $16.0 \%$ dry weight) (Kihlberg, 1972). Therefore, the content of nucleic acids in edible mushrooms is considered to be safe to eat as a daily vegetable ( $\mathbf{L i} \&$ Chang, 1982 b). Extensive clinical studies, primarily in Japan, have clearly demonstrated that a number of species have medical and therapeutic value, by injection or oral administration, in the prevention / treatment of cancer, viral diseases (influenza, polio), hypercholesterolemia, blood platelet aggregation and hypertension (Breene, 1990 and Chang and Miles, 1993).

Consumption of processed cheese increased markedly in Egypt during the last two decades. Abeid et al (2001) used shrimps in manufacturing processed cheese spread. Factors contributing to the continued growth and success of these products, such as they offer almost unlimited variety in flavour, consistency, functionality (e.g. meltability, sliceability, flowability), and consumer appeal as a result of differences in formulation, processing conditions, and packaging into various shapes and sizes. Also, they are adaptable to the fast-food trade, have a relatively long shelf- life and waste is minimal (Fox et al 2000). Meyer (1973) and Mladenova (1977) studied the possibilities of using mushroom as a component of processed cheese.

This study is an attempt to fortification the processed cheese spreads with accustomed edible mushroom (Agaricus campestris), and to investigate the effect of incorporating such a mushroom into processed cheese spreads on the chemical, microbiological and sensory properties. 
MATERIAL AND METHODS

\section{Materials}

Ras cheese (one month old) was obtained from Arabic Food Industrial Co. (Domety) $6^{\text {th }}$ October city, Egypt. Also, matured Cheddar cheese (8 months old) and Kasomel emulsifying salt K-2394 (Rhone-Poulenc Chimie, France) were obtained from International Dairy \&foods Co. (Milky Land), $10^{\text {th }}$ Ramadan city, Egypt. Low heat skim milk powder and butter were procured from Irish Dairy Board, Grattan House, Lower Mount St., Dublin, Ireland. Edible mushroom (Agaricus campestris) was purchased from Fac. Agric., Ain Shams Univ., Cairo, Egypt. The chemical composition of the ingredients used in the manufacturing processed cheese spreads is presented in Table (1).

\section{Experimental procedure}

\section{A. Accustoming mushroom}

Mushroom corpuscles were steeped into $0.1 \mathrm{M}$ citric acid for $1 \mathrm{hr}$ at room temperature. Thereafter, it's been cut into tiny pieces with a sharp knife. The mushroom pieces were boiled into $1 \%$ Kasomel emulsifying salt solution $(\sim \mathrm{pH}$ $=9.0$ ) for $15 \mathrm{~min}$.

\section{B. Manufacture of processed cheese spreads (PCSs)}

Processed cheese spreads were manufactured, according to the method of Meyer (1973), from young Ras and matured Cheddar cheeses as a base blend. Cheeses were weighed, minced, ground and placed into the processing batch type kettle of $10 \mathrm{~kg}$ capacities, a pilot machine at the National Research Center.

Calculated balanced amounts of emulsifying salt $(2.5 \%)$, butter, skim milk powder and water were simultaneously added. The mushroom tiny pieces were added to the base blend at the levels of 0 (control), 5,10 and 15 $\%$. The composition of each batch of processed cheese treatments was adjusted to contain a final product, as nearly as possible, with $55 \pm 1 \%$ moisture and 50 $\pm 1 \%$ fat in dry matter to similar the processed cheese made traditionally according to the Egyptian Standards (1988). All blends were cooked with controlled agitation for $8 \mathrm{~min}$ at $85-90^{\circ} \mathrm{C}$ using direct injection steam at pressure of 1.5 bar. The hot product of PCSs was manually filled into $150 \mathrm{cc}$. sterilized glass jar and also covered with aluminum foil and their covers, then rapidly cooled at $7 \pm 1^{\circ} \mathrm{C}$. The resulting PCSs were analyzed when fresh and after $1 \& 3$ months. The compositions of different blends of PCSs are shown in Table (2). Three replicates of each treatment were manufactured and subjected to analysis.

\section{Methods}

\section{A. Analysis of edible mushroom}

Fresh edible mushroom was chemically analysed for $\mathrm{pH}$ value (using $\mathrm{pH}$ meter model Cole-Armer Instrument Co., USA), moisture, ash, total carbohydrate, total nitrogen (using microKjeldahal method), crude fat and fiber contents according to the methods described by Nielsen, (1998).

\section{B. Chemical analysis of PCSs}




\section{Fortification of processed cheese spread}

The PCSs samples were tested for fat content (using Gerber method), total nitrogen and soluble nitrogen (SN) contents (using micro-Kjeldahal method), and

also $\mathrm{pH}$ values (using $\mathrm{pH}$ meter model Cole-Armer Instrument Co., USA) as described in Ling, (1963). The salt content was determined as described by Marshall, (1992). Total volatile fatty acids (TVFA) were determined by the method of Kosikowski, (1970), and values were expressed as $\mathrm{ml} 0.1 \mathrm{~N} \mathrm{NaOH}$ $/ 100 \mathrm{~g}$. Also, the moisture and ash contents 
Arab Univ. J. Agric. Sci., Ain Shams Univ., Cairo, 13(3), 825 - 839, 2005

Table 1. Chemical composition (\%) of the ingredients used in manufacture of processed cheese spread

\begin{tabular}{|c|c|c|c|c|c|}
\hline \multirow{2}{*}{$\begin{array}{c}\text { Composition } \\
(\%)\end{array}$} & \multicolumn{5}{|c|}{ Ingredients } \\
\hline & $\begin{array}{l}\text { Cheddar } \\
\text { cheese }\end{array}$ & $\begin{array}{c}\text { Ras } \\
\text { cheese }\end{array}$ & $\begin{array}{l}\text { Skim milk } \\
\text { powder }\end{array}$ & Butter & $\begin{array}{c}\text { Fresh } \\
\text { mushroom }\end{array}$ \\
\hline \multirow[t]{2}{*}{ Total solids } & 65.80 & 54.81 & 96.00 & 84.00 & 10.50 \\
\hline & \pm 0.16 & \pm 0.18 & \pm 0.05 & \pm 0.02 & \pm 0.50 \\
\hline \multirow[t]{2}{*}{ Fat } & 34.80 & 24.77 & 0.99 & 81.99 & 0.15 \\
\hline & \pm 0.10 & \pm 0.12 & \pm 0.02 & \pm 0.06 & \pm 0.10 \\
\hline \multirow[t]{2}{*}{ Total protein } & $25.47^{1}$ & $22.26^{1}$ & $37.13^{1}$ & $\mathrm{ND}^{2}$ & $3.34^{3}$ \\
\hline & \pm 0.09 & \pm 0.12 & \pm 0.06 & & \pm 0.19 \\
\hline \multirow[t]{2}{*}{ Soluble nitrogen } & 1.20 & 0.67 & 0.83 & ND & ND \\
\hline & \pm 0.99 & \pm 0.87 & \pm 0.03 & & \\
\hline \multirow[t]{2}{*}{ Salt } & 1.53 & 2.67 & ND & ND & ND \\
\hline & \pm 0.13 & \pm 0.11 & & & \\
\hline \multirow[t]{2}{*}{ Ash } & 5.42 & 5.76 & 7.89 & ND & 0.74 \\
\hline & \pm 0.19 & \pm 0.13 & \pm 0.10 & & \pm 0.15 \\
\hline \multirow[t]{2}{*}{$\mathrm{pH}$} & 5.02 & 5.35 & 6.40 & ND & 6.80 \\
\hline & \pm 0.05 & \pm 0.05 & \pm 0.06 & & \pm 0.02 \\
\hline \multirow[t]{2}{*}{$\mathrm{TVFA}^{4}$} & 29.10 & 24.65 & ND & ND & ND \\
\hline & \pm 1.87 & \pm 1.00 & & & \\
\hline \multirow{2}{*}{$\begin{array}{l}\text { Total } \\
\text { carbohydrate }\end{array}$} & 0.10 & 1.64 & 47.43 & ND & ND \\
\hline & \pm 0.01 & \pm 0.20 & \pm 0.81 & & \\
\hline \multirow[t]{2}{*}{ Fiber } & ND & ND & ND & ND & 0.71 \\
\hline & & & & & \pm 0.20 \\
\hline
\end{tabular}

${ }^{1}$ Protein $\%=\mathrm{N} \times 6.38$.

${ }^{3}$ Protein $\%=\mathrm{N} \times 4.38$.

${ }^{2}$ Not determined.

${ }^{4}$ Total volatile fatty acids.

1- Dairy Science Dept., National Research Center, Dokki, Giza, Egypt.

2- Food Sci. Dept., Fac. Agric., Ain Shams Univ., Shoubra EL-Khaima, Cairo, Egypt.

(Received May 11, 2005)

(Accepted June 8, 2005) 
Fortification of processed cheese spread

Table 2. Composition $(\mathrm{kg} / 100 \mathrm{~kg})$ of different blends used in manufacture of processed cheese spread

\begin{tabular}{|lcccc|}
\hline \multirow{2}{*}{ Ingredients } & Control & \multicolumn{3}{c|}{ Ratios of mushroom $(\%)$} \\
\cline { 3 - 5 } & & 5 & 10 & 15 \\
\hline Cheddar cheese & 12.80 & 12.80 & 12.80 & 12.80 \\
Ras cheese & 38.44 & 38.44 & 38.44 & 38.44 \\
Skim milk powder & 5.12 & 5.12 & 5.12 & 5.12 \\
Butter & 10.26 & 10.26 & 10.26 & 10.26 \\
Emulsifying salt & 2.50 & 2.50 & 2.50 & 2.50 \\
Mushroom & - & 5.00 & 10.00 & 15.00 \\
Water & 30.88 & 25.88 & 20.88 & 15.88 \\
Total & 100 & 100 & 100 & 100 \\
\hline
\end{tabular}

were determined according to the method in AOAC, (1990). Total carbohydrate and crude fiber contents were determined according to the method described by Nielsen (1998).

\section{Microbiological analysis}

Samples of all cheeses were prepared for microbiological analysis according to the method described in the Standard Methods for the Examination of Dairy Products (Marshall, 1992) and Vanderzant \& Splittstoesser (1992). All PCSs samples was examined for (a) the standard plate counts and (b) psychrotrophic counts on plate count agar (Oxoid) at $32 \pm 1^{\circ} \mathrm{C}$ for $48 \pm 3 \mathrm{hr}$ and 7 $\pm 1^{\circ} \mathrm{C}$ for 10 day, respectively, (c) yeasts and molds counts on acidified potato dextrose agar (Oxoid) at $25^{\circ} \mathrm{C}$ for 5 days, (d) coliform counts on violet red bile agar (Oxoid) at $37 \pm 1^{\circ} \mathrm{C}$ for $24 \pm 2 \mathrm{hr}$ and (e) mesophilic anaerobic sporeformers counts on Reinforced clostridial medium (Oxoid) using anaerobic jar at $30-35^{\circ} \mathrm{C}$ for $48 \mathrm{~h}$. The results expressed as colony forming unit $(\mathrm{CFU}) / \mathrm{g}$.

\section{Organoleptic assessment}

The organoleptic properties of PCSs samples were evaluated by 15 regular taste panels of the staff members at the Food Science Department, Fac. Agric., Ain Shams Univ. and National Research Center, according to the scheme of Meyer, (1973). The organoleptic scheme used consisted of flavour (40 points), body \& texture ( 40 points) and appearance $\&$ colour (20 points).

\section{Statistical analysis}

The obtained results were statistically analyzed using the general linear models procedure of the Statistical Analysis System (SAS, 1996). Significance of differences was defined at $p<0.05$. 
Arab Univ. J. Agric. Sci., Ain Shams Univ., Cairo, 13(3), 825 - 839, 2005

\section{RESULTS AND DISCUSSION}

\section{Chemical composition of PCSs}

The changes in gross chemical composition of PCSs made with incorporation of edible mushroom accustomed to the blend of the cheese spread base at the levels of 5,10 and 15 $\%$ during storage at $7 \pm 1^{\circ} \mathrm{C}$ for 3 months are shown in Table (3). Significant differences $(p<0.05)$ were recorded among the chemical composition of PCSs made without and with incorporation of mushroom. PCSs made with incorporation of mushroom accustomed had higher contents of total solids, total protein, $\mathrm{SN}$, ash, total carbohydrates and fiber than the control spread. On the other hand, control treatment made without mushroom possessed the highest content of $\mathrm{F} / \mathrm{DM}$. Increasing the percentage of mushroom added in the formula increased the contents of total solids, total protein, $\mathrm{SN}$, ash, total carbohydrates and fiber, and also decreased the F/DM in the resulting PCSs. Addition of 5, 10 and $15 \%$ mushroom in the base blend of PCSs did not significantly affect $(p>0.05)$ in the salt and TVFA contents with the control cheese. The highest contents of ash, total protein, carbohydrates as well as fiber in PCSs with incorporation of mushroom accustomed are mainly due to the higher contents of these components in mushroom used in fortification of PCSs. However, the $\mathrm{pH}$ of control spread had the lowest value as compared with PCSs with mushroom. In the other means, PCSs made with different ratios of mushroom had the highest values of $\mathrm{pH}$. The $\mathrm{pH}$ values were increased to more extent in the resulting PCSs when the percentage of added mushroom increasing. This could be due to the higher $\mathrm{pH}$ value of mushroom using in the formula $(\sim \mathrm{pH}=6.80)$. These results are in agreement with Al-Khamy et al (1997); Hamed et al (1997) and Khader et al (1997). Meyer, (1973) mentioned that the important reasons for adding some ingredients to processed cheeses is to increase protein content. Also, analyses of the proximate composition of the commonly cultivated mushrooms reveal that edible mushrooms are rich in crude protein and carbohydrates, moderate in crude fiber and ash, and low in fat content (Lau, 1982).

During the storage period at the refrigerator temperature for 3 months, the chemical composition of PCSs treatments was very slightly changed $(p>0.05)$. All components content were increased in all treatments; except the $\mathrm{pH}$ values and total carbohydrates content were decreased during the storage period. The slight reduction in $\mathrm{pH}$ values and total carbohydrates content during the storage period could be attributed to a limitation growth and activity of resistant microflora, such as heat resistant proteinases or psychrotrophic bacteria present and enzymes in the product, which cause a hydrolysis of lactose to some acids. It could be also due to the hydrolysis of polymerized phosphate present in the emulsifying salts and their interaction with protein. These results

1- Dairy Science Dept., National Research Center, Dokki, Giza, Egypt.

2- Food Sci. Dept., Fac. Agric., Ain Shams Univ., Shoubra EL-Khaima, Cairo, Egypt.

(Received May 11, 2005)

(Accepted June 8, 2005) 


\section{Fortification of processed cheese spread}

agree with many researches (Tamime $\boldsymbol{e t}$ al 1990; Younis et al 1991 and Aly et al 1995).

\section{Microbiological quality of PCSs}

The changes in microbiological quality $(\mathrm{CFU} / \mathrm{g})$ of PCSs made with incorporation of edible mushroom accustomed to the blend of the cheese spread base at the levels of 5, 10 and 15 $\%$ during storage at $7 \pm 1^{\circ} \mathrm{C}$ for 3 months are shown in Table (4). The standard plate and psychrotrophic counts of PCSs made 
Arab Univ. J. Agric. Sci., Ain Shams Univ., Cairo, 13(3), 825 - 839, 2005

1- Dairy Science Dept., National Research Center, Dokki, Giza, Egypt.

2- Food Sci. Dept., Fac. Agric., Ain Shams Univ., Shoubra EL-Khaima, Cairo, Egypt.

(Received May 11, 2005)

(Accepted June 8, 2005) 
11

Fortification of processed cheese spread

Table 4. Changes in microbiological quality $\left(\mathrm{CFU}^{1 / \mathrm{g}}\right)$ of processed cheese spreads made with incorporation of edible mushroom accustomed during storage at $7^{\circ} \mathrm{C}$ for 3 months

\begin{tabular}{|cccc|}
\hline $\begin{array}{c}\text { Ratios of } \\
\text { mushroom } \\
(\%)\end{array}$ & $\begin{array}{c}\text { Storage } \\
\text { period } \\
(\text { month })\end{array}$ & $\begin{array}{c}\text { Standard } \\
\text { plate counts }\end{array}$ & $\begin{array}{c}\text { Psychrotrophic } \\
\text { counts }\end{array}$ \\
\hline 0 & Fresh & $45 \times 10^{2 \mathrm{a}}$ & $2.3 \times 10^{\mathrm{a}}$ \\
$($ control $)$ & 1 & $50 \times 10^{2 \mathrm{~b}}$ & $2.6 \times 10^{\mathrm{b}}$ \\
& 3 & $46 \times 10^{2 \mathrm{a}}$ & $2.8 \times 10^{\mathrm{bcd}}$ \\
5 & Fresh & $44 \times 10^{2 \mathrm{a}}$ & $2.5 \times 10^{\mathrm{b}}$ \\
& 1 & $51 \times 10^{2 \mathrm{be}}$ & $2.8 \times 10^{\mathrm{bcd}}$ \\
& 3 & $48 \times 10^{2 \mathrm{c}}$ & $3.0 \times 10^{\mathrm{cd}}$ \\
10 & Fresh & $46 \times 10^{2 \mathrm{a}}$ & $2.4 \times 10^{\mathrm{b}}$ \\
& 1 & $53 \times 10^{2 \mathrm{~d}}$ & $2.7 \times 10^{\mathrm{bcd}}$ \\
& 3 & $50 \times 10^{2 \mathrm{~b}}$ & $2.9 \times 10^{\mathrm{cd}}$ \\
15 & Fresh & $48 \times 10^{2 \mathrm{c}}$ & $2.6 \times 10^{\mathrm{cb}}$ \\
& 1 & $52 \times 10^{2 \mathrm{de}}$ & $2.9 \times 10^{\mathrm{cd}}$ \\
& 3 & $51 \times 10^{2 \mathrm{be}}$ & $3.1 \times 10^{\mathrm{d}}$ \\
\hline
\end{tabular}

${ }^{1}$ Colony forming unit.

$\mathrm{a}, \mathrm{b}, \mathrm{c} . .$. : Means with the different letters within the same column are significantly different $(p<0.05)$.

Arab Univ. J. Agric. Sci., 13(3), 2005 
with incorporation of mushroom accustomed were slightly different when fresh and during the storage period. PCSs made with different ratios of mushroom had slightly higher counts of standard plate and psychrotrophic bacteria at the end of storage period than the control treatment. This is may be due to that the $\mathrm{pH}$ of treated spreads with mushroom; ranged from 5.84 to 5.93; were more suitable for growth of these microorganisms than the control spread $(\mathrm{pH}=5.75)$. The standard plate counts slightly increased during the storage period reaching the maximum counts after one month, and then decreased with prolonged storage. Psychrotrophic bacteria gradually increased in all treatments during the storage at the refrigerator temperature for 3 months. On the other hand, no colonies were found from yeasts and molds, coliform and mesophilic anaerobic spores in all samples examined. These results in agreement with Mahfouz et al (1986) and Abd-Alla et al (1996), they mentioned that these results were reasonable quality. Magdoub et al (1984) reported that the decrease in counts at the end of the storage period might be due to decreasing in the $\mathrm{pH}$ values, the relatively high salt content and improper redox potential. Also, they mentioned that the absence of some microorganisms examined such as yeasts and molds may be due to that they usually destroyed during the heat processing applied to cheese spreads, unfavorable $\mathrm{pH}$ and relatively high salt content may help in preventing the growth of these organisms.

\section{Organoleptic properties}

The organoleptic properties of PCSs made with incorporation of edible mushroom accustomed to the blend of the cheese spread base at the levels of 5,10 and $15 \%$ during storage at $7 \pm 1^{\circ} \mathrm{C}$ for 3 months are shown in Table (5). Obvious differences $(p<0.05)$ were noticed in the organoleptic evaluation scores among all treatments of PCSs. Control spread had a sharp flavour and light yellow colour, due to the hard cheeses used in the formula. The flavour of PCSs with incorporation of mushroom accustomed was generally better and preferable by the panelists when fresh and throughout the storage period. Moreover, PCSs made with different ratios of mushroom characterized by found tiny pieces of mushroom that was favorable from the panelists, especially at the levels of 5 and $10 \%$ of added mushroom. Also, the body\& texture and appearance $\&$ colour were more accepted from the panelists than the control spreads. Generally, the organoleptic properties of PCSs made with 5 and $10 \%$ of mushroom were the best, respectively during the refrigerator storage as compared with the other treatments. Addition 
Arab Univ. J. Agric. Sci., Ain Shams Univ., Cairo, 13(3), 825 - 839, 2005

of $15 \%$ mushroom caused an over pieces of mushroom, which defected the body $\&$ texture and appearance \& colour of the resulting spread. No browning colour was found in PCSs made with mushroom, due to the treatment assessed of mushroom before adding to base blend.

Rajarathnam et al (2003) reported that sodium carbonate at the concentration of $0.1 \mathrm{M}$ favored the immediate development of an orange chromogen in mushroom, while mild alkaline solutions favored the enzyme activity, and acidic solutions at the $0.1 \mathrm{M}$ levels completely inhibited the browning reaction in mushroom. During the storage at the refrigerator temperature up to 3 months, the sensory scores of PCSs samples were increased after one month of storage (Table, 5), and then there were a decrease at the end of the storage. These improvements could be related to the slightly changes in the chemical composition of the PCSs (Hamed et al 1997 and Abeid et al 2001). Also, Meyer, (1973) mentioned that the additional ingredients at a maximum of $15 \%$ do not influence the consistency and structure of processed cheese to any appreciable extent. Moreover, mushrooms may be consumed for their palatability and/or nutritional value (Chang and Miles, 1993).

Finally, PCSs with improved nutritional and functional values as well as acceptable organoleptic properties and good microbiological quality could be made by incorporation of accustomed edible mushroom into the base blend at the levels of 5 and $10 \%$ with refrigerated expiry period more than 3 months.

1- Dairy Science Dept., National Research Center, Dokki, Giza, Egypt.

2- Food Sci. Dept., Fac. Agric., Ain Shams Univ., Shoubra EL-Khaima, Cairo, Egypt.

(Received May 11, 2005)

(Accepted June 8, 2005) 
Arab Univ. J. Agric. Sci., Ain Shams Univ., Cairo, 13(3), 825 - 839, 2005

Table 5. Organoleptic properties of processed cheese spreads made with incorporation of edible mushroom accustomed during storage at $7^{\circ} \mathrm{C}$ for 3 months

\begin{tabular}{|c|c|c|c|c|c|}
\hline \multirow{2}{*}{$\begin{array}{c}\text { Ratios of } \\
\text { mushroom } \\
(\%)\end{array}$} & \multirow{2}{*}{$\begin{array}{l}\text { Storage } \\
\text { Period } \\
\text { (month) }\end{array}$} & \multicolumn{4}{|c|}{ Character assessed } \\
\hline & & $\begin{array}{l}\text { F. }{ }^{1} \\
(40)\end{array}$ & $\begin{array}{c}\text { B.\& T. }{ }^{2} \\
\quad(40)\end{array}$ & $\begin{array}{c}\text { A. \& C. }{ }^{3} \\
\quad(20)\end{array}$ & $\begin{array}{l}\text { T. S. }{ }^{4} \\
(100)\end{array}$ \\
\hline 0 & Fresh & $37.0^{\mathrm{ae}}$ & $36.3^{a b}$ & $18.0^{\mathrm{a}}$ & $91.3^{\mathrm{a}}$ \\
\hline \multirow[t]{2}{*}{ (control) } & 1 & $38.0^{\text {bd }}$ & $36.5^{\mathrm{a}}$ & $18.0^{\mathrm{a}}$ & $92.5^{b c}$ \\
\hline & 3 & $37.5^{\text {ad }}$ & $36.0^{b c}$ & $17.5^{b}$ & $91.0^{\mathrm{a}}$ \\
\hline \multirow[t]{3}{*}{5} & Fresh & $39.3^{c}$ & $36.5^{\mathrm{a}}$ & $18.3^{\mathrm{ad}}$ & $94.1^{\mathrm{e}}$ \\
\hline & 1 & $39.5^{\mathrm{c}}$ & $36.5^{\mathrm{a}}$ & $18.5^{\mathrm{cd}}$ & $94.5^{\mathrm{e}}$ \\
\hline & 3 & $39.0^{\mathrm{c}}$ & $36.3^{a b}$ & $17.5^{b}$ & $92.8^{b c}$ \\
\hline \multirow[t]{3}{*}{10} & Fresh & $38.5^{b}$ & $36.0^{\mathrm{bc}}$ & $17.5^{b}$ & $92.0^{\mathrm{c}}$ \\
\hline & 1 & $38.5^{b}$ & $36.5^{\mathrm{a}}$ & $18.0^{\mathrm{a}}$ & $93.0^{\mathrm{d}}$ \\
\hline & 3 & $38.3^{\mathrm{bd}}$ & $35.7^{c}$ & $17.5^{b}$ & $91.5^{\mathrm{a}}$ \\
\hline \multirow[t]{3}{*}{15} & Fresh & $37.3^{\mathrm{a}}$ & $35.5^{\mathrm{c}}$ & $17.0^{\mathrm{e}}$ & $89.8^{f}$ \\
\hline & 1 & $37.5^{\mathrm{ad}}$ & $35.0^{\mathrm{d}}$ & $16.6^{\mathrm{ef}}$ & $88.5^{\mathrm{g}}$ \\
\hline & 3 & $37.0^{\mathrm{ae}}$ & $34.4^{\mathrm{e}}$ & $16.5^{\mathrm{f}}$ & $87.9^{\mathrm{g}}$ \\
\hline
\end{tabular}

${ }^{1}$ Flavour

${ }^{3}$ Appearance \& colour

${ }^{2}$ Body \& texture.

${ }^{4}$ Total score.

$\mathrm{a}, \mathrm{b}, \mathrm{c} . .$. : Means with the different letters within the same column are significantly different $(p<0.05)$.

\section{REFERENCES}

Abd-Alla, E.A.M.; K. El-Shafei; G.A. Ibrahim and O.M. Sharaf (1996). Changes in microflora and biogenic amines of some market processed cheeses during storage. Egyptian J. Dairy Sci. 24(2): 217-226.

Abeid, A.M.; M.A. El-Aassar and A.H. El-Sonbaty (2001). The use of shrimps in processed cheese spread. Egyptian $\boldsymbol{J}$. Dairy Sci., 29(1): 127-137.

1- Dairy Science Dept., National Research Center, Dokki, Giza, Egypt.

2- Food Sci. Dept., Fac. Agric., Ain Shams Univ., Shoubra EL-Khaima, Cairo, Egypt.

(Received May 11, 2005)

(Accepted June 8, 2005) 
Arab Univ. J. Agric. Sci., Ain Shams Univ., Cairo, 13(3), 825 - 839, 2005

Al-Khamy, A.F.; G.A. El-Garawany; A.Khader; A. Hamed and M.H. Abd El-Salam (1997). The use of whey protein concentrates in processed cheese spreads.1.Effect of type of emulsifying salts. Egyptian J. Dairy Sci., 25(1): 99112.

Aly, M.E.; A.A. Abdel-Baky; S.M. Farahat and U.U.B. Hana (1995). Quality of processed cheese spread made using ultrafiltrated retentates treated with some ripening agents. International Dairy J.5, Issue 2: 191-209.

Anderson, J.W. and K. Ward (1979). High-carbohydrate high- fiber diets for insulin- treated men with diabetes mellitus. Am. J. Clin. Nutr. 32: 23122321.

AOAC (1990). Official Methods of Analysis $\left(15^{\text {th }}\right.$ Ed.), pp. 840-850. Association Official Analytical Chemists. Arlington VA, USA.

Breene, W.M. (1990). Nutritional and medicinal value of specialty mushrooms. J. Food Prot., 53(10): 883-894.

Chambre, M. and J. Daurelles (2000). Processed cheese. In: Cheesemaking from Science to Quality Assurance. $\left(3^{\mathrm{rd}}\right.$ Ed.), pp. 641-657. Eck, A. and J.C. Gillis (eds.). Veterinaer, Danmarks.

Chang, S.T. and P.G. Miles (eds.) (1993). The nutritional attributes and medical value of edible mushrooms. In: Edible Mushrooms and Their Cultivation. pp. 27-40. CBS Publishers \& Distributors, India.

Crisan, E.V. and A. Sands (1978). Nutritional value. In: The Biology and Cultivation of Edible Mushrooms. p.
137. Chang, S.T. and W.A. Hayes (eds.). Academic Press, New York.

Egyptian Standards (1988). Processed cheese. Part II. Spreadable processed cheese.pp.3-5. Egyptian Organization for Standardization and Quality Control, Cairo.

Fox, P.F.; T.P. Guinee; T.M. Cogan and Paul L.H. McSweeney (eds.) (2000). Processed cheese and substitute or imitation cheese products. In: Fundamentals of Cheese Science. p. 429. Aspen Publishers, Inc., Maryland, USA.

Hamed, A.; A. Khader; A.F. AlKhamy; G.A. El-Garawany and M.H. Abd El-Salam (1997). Effect of storage on the composition, rheological properties and organoleptic quality of commercial processed cheeses. Egyptian J. Dairy Sci., 25 (1): 113-122.

Holman, R.T. (1976). Significance of essential fatty acids in human nutrition. In: Lipids. Vol. 1, p.215. Paoletti, R.; G. Poscellati and G. Jasina (eds.). Raven Press, New York.

Khader, A.; A. Hamed; A.F. AlKhamy; G.A. El-Garawany and M.H. Abd El-Salam (1997). Chemical composition and some properties of market processed cheese. Egyptian $\boldsymbol{J}$. Dairy Sci. 25 (2): 269-279.

Kihlberg, R. (1972). The microbe as a source of food. In: Annual Review of Microbiology. p. 427. Clifton, L.E.; S. Raffel and M.P. Starr (eds.). Annual Reviews, Palo Alto, California.

Kosikowski, F.V. (ed.) (1970). In: Cheese and Fermented Milk Foods.

1- Dairy Science Dept., National Research Center, Dokki, Giza, Egypt.

2- Food Sci. Dept., Fac. Agric., Ain Shams Univ., Shoubra EL-Khaima, Cairo, Egypt.

(Received May 11, 2005)

(Accepted June 8, 2005) 
16

Fatma; Gehan and Mohamed

$\left(3^{\text {rd }}\right.$ Ed.). pp. 352-354. Edwards Brothers, Inc., Ann. Arbor, Michigan, USA.

Lau, O.W. (1982). Methods of chemical analysis of mushrooms. In: Biological Nature and Cultivation Methods. p. 87. Chang, S.T. and T.H. Quimio (eds.). The Chinese University Press, Hong Kong.

Li, G.S.F. and S.T. Chang (1982a). Nutritive value of Volvariella volvacea. In: Tropical Mushrooms, Biological Nature and Cultivation Methods. p.199. Chang, S.T. and T.H. Quimio (eds.). The Chinese University Press, Hong Kong.

Li, G.S.F. and S.T. Chang (1982b). The nucleic acid content of some edible mushrooms. European J. Appl. Microbiol. Biotechnol. 15(4): 237- 240. Ling, E.F. (ed.) (1963). A Text Book of Dairy Chemistry. Vol. 2, Practical, $\left(3^{\text {rd }}\right.$ Ed.), pp. 58-65. Chapman and Hall Ltd., London.

Magdoub, M.N.I.; A.E. Shehata; A. Gouda and A.A. Hofi (1984). The chemical, microbiological and sensory properties of processed Ras cheese spread. Egyptian J. Dairy Sci. 12(1): 3746.

Mahfouz, M.B.; H.F. El-Dien; S. ElShibiny; H.F. Haggag and M.N.I. Magdoub (1986). Chemical and microbiological quality of marked processed cheese. Egyptian J. Dairy Sci. 14(1): 33-41.

Marshall, R.T. (ed.) (1992). In: Standard Methods for the Examination of Dairy Products. $\left(16^{\text {th }}\right.$ Ed.), pp. 433531. Amer. Public Health Assoc., Washington, DC.

Meyer, A. (ed.) (1973). In: Processed Cheese Manufacture. ( $1^{\text {st }}$ Ed.), pp. 98277. Food Trade Press Ltd., London, UK. Mladenova, I. (1977). Possibilities of using mushroom mycelia as a component of processed cheese. Khranitelna promishlenost Khranit Prom st 26(9): 29-30 (English abstract).

Nielsen, Suzanne S. (ed.) (1998). In: Food Analysis. (2 ${ }^{\text {nd }}$ Ed.), pp. 167-215. Aspen Publishers, Inc., Maryland.

Rajarathnam, S.; M.N. Shashirekha and S. Rashmi (2003). Biochemical changes associated with mushroom browning in Agaricus bisporus (Lange) Imbach and Pleurotus florida (Block \& Tsao): commercial implications. J. Sci. Food \& Agric. 83, Issue (14): 15311537.

SAS (1996). Statistical Analysis System. SAS User's Guide: Statistics, Release 6.12 Education. SAS Inst. Inc. Cary. NC., USA.

Tamime, A.Y.; M.F. Younis; G. Davies and I. Bnadbury (1990). The quality of processed cheese made from reconstituted skim milk powder cheese base. Egyptian J.Dairy Sci. 18(1): 115131.

Vanderzant, C. and D.F. Splittstoesser (eds.) (1992). In: Compendium of Methods for the Microbiological Examination of Foods. pp. 849-853. Amer. Public Health Assoc., Washington, DC.

Weaver, J.C.; M. Kroger and L.R. Kneebone. (1977). Comparative protein studies (Kjeldahl, dye binding, amino acid analysis) of nine strains of Agaricus bisporus (Lange) Imbach mushrooms. $\boldsymbol{J}$. Food Sci. 42(2): 364-366.

Yoshioka, Y.; M. Emori; J. Ikekawa and F. Fukuoka (1975). Isolation, purification and structure of components from acidic polysaccharides of Pleurotus ostreatus (Fr.) Qual. Carbohydrate Res. 43,Issue: 305 - 320.

Younis, M.F.; A.Y. Tamime; G. Davies; E.A. Hunter; A.H. Dawood and 
Fortification of processed cheese spread

S.M. Abdo (1991). Production of and cheese base .3.Compositional quality. processed cheese using Cheddar cheese Milchwissenschft 46: 566 -569. 
Arab Univ. J. Agric. Sci., Ain Shams Univ., Cairo, 13(3), 825 - 839, 2005

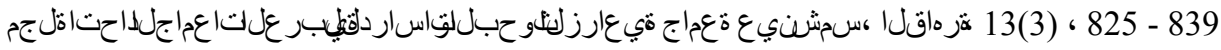
، 2005

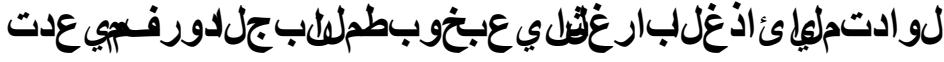

]55[

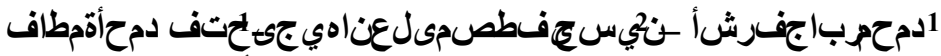

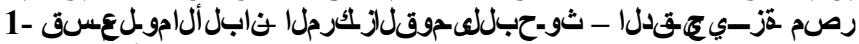

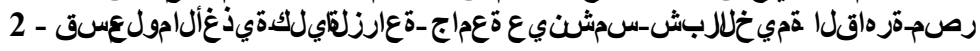

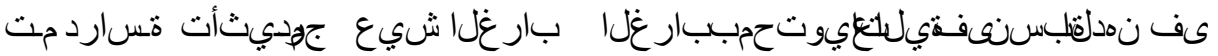

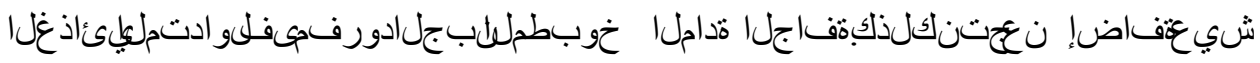

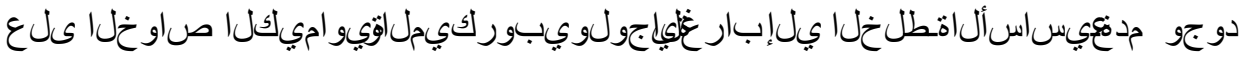

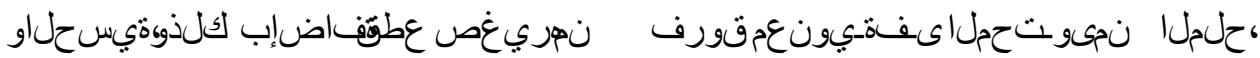

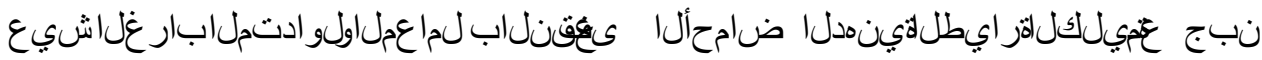

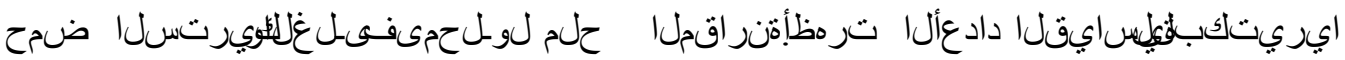

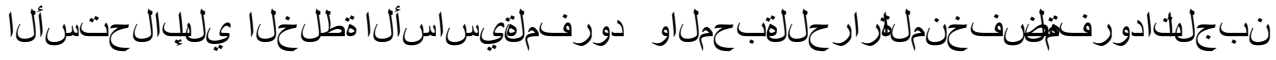

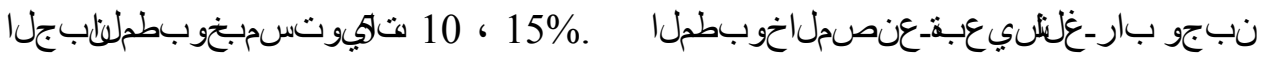

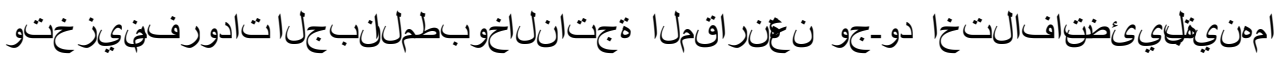

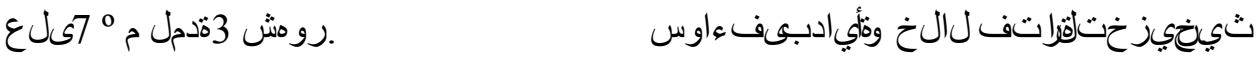

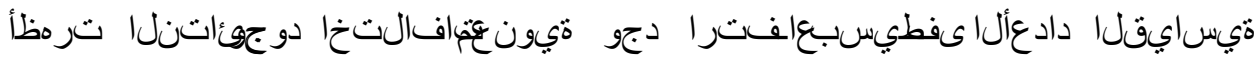

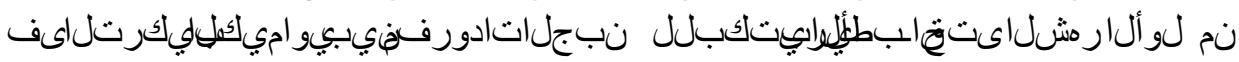

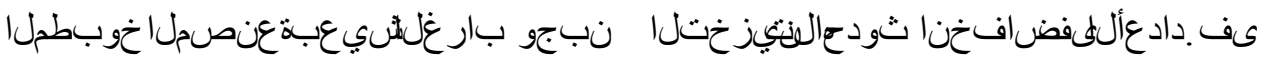

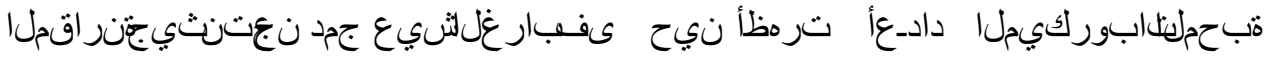

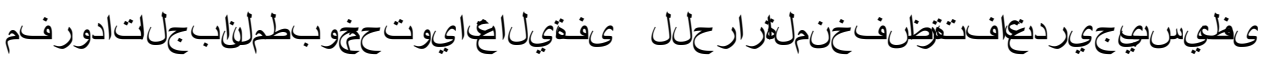

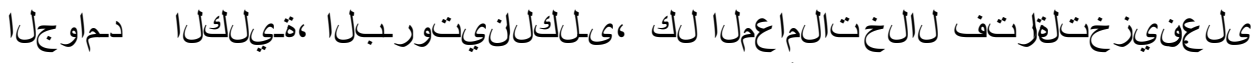

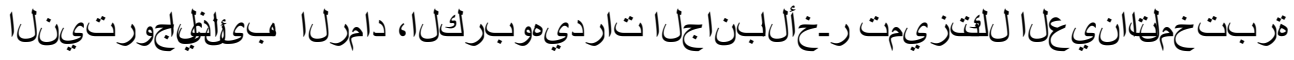

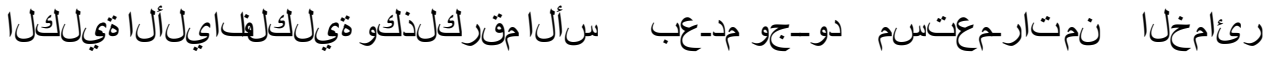

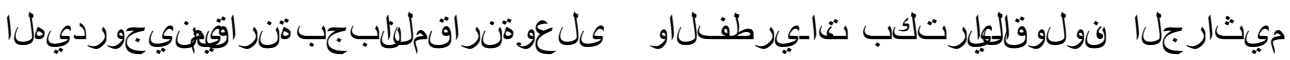

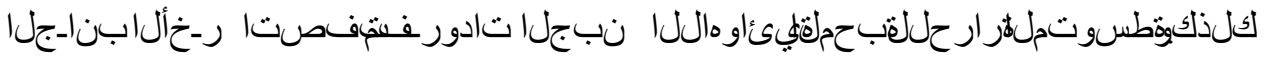

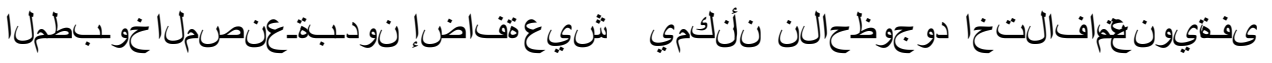

1- Dairy Science Dept., National Research Center, Dokki, Giza, Egypt.

2- Food Sci. Dept., Fac. Agric., Ain Shams Univ., Shoubra EL-Khaima, Cairo, Egypt.

(Received May 11, 2005)

(Accepted June 8, 2005) 
Arab Univ. J. Agric. Sci., Ain Shams Univ., Cairo, 13(3), 825 - 839, 2005

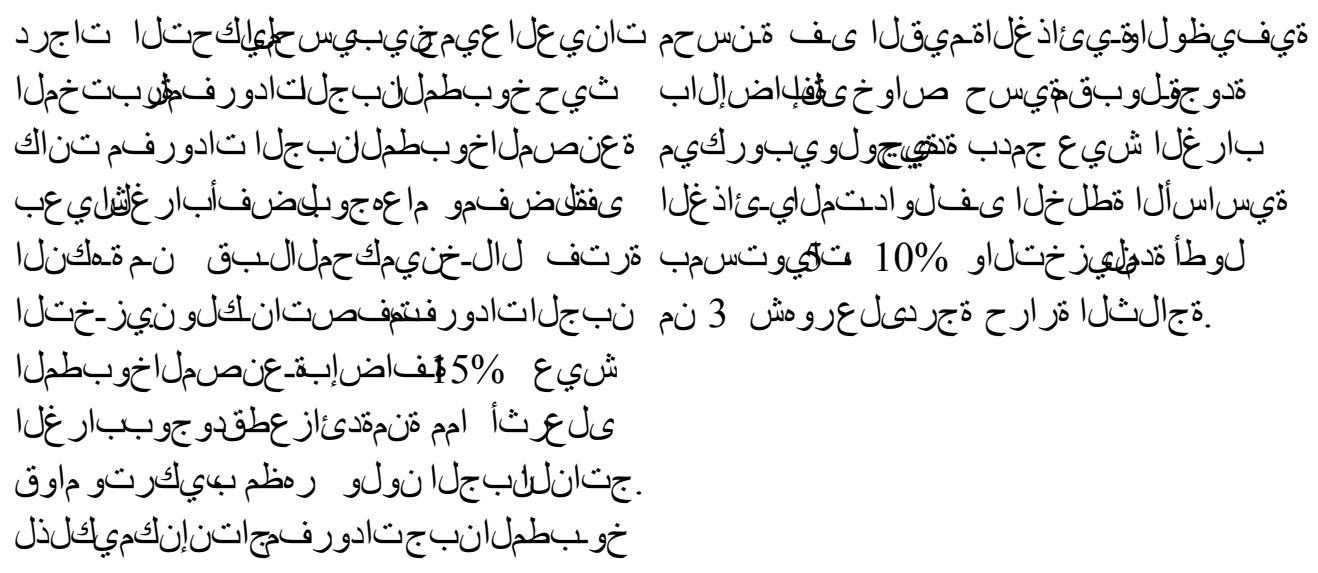

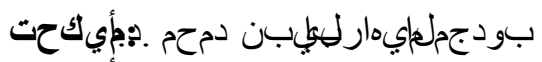

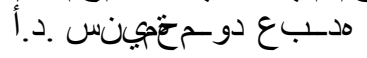

1- Dairy Science Dept., National Research Center, Dokki, Giza, Egypt.

2- Food Sci. Dept., Fac. Agric., Ain Shams Univ., Shoubra EL-Khaima, Cairo, Egypt.

(Received May 11, 2005)

(Accepted June 8, 2005) 